\title{
ETOS BISNIS ETNIS MADURA PERANTAUAN DI KOTA MALANG: MEMAHAMI DIALEKTIKA AGAMA DENGAN KEARIFAN LOKAL
}

\author{
Muhammad Djakfar \\ Fakultas Ekonomi Universitas Islam Negeri (UIN)Maulana Malik Ibrahim Malang \\ Jln. Gajayana 50 Malang \\ E-mail:dj4kfar.2010@gmail.com / HP.08155524601
}

\begin{abstract}
Abstrak
The Madurese ethnic is known as one of the diverse ethnic groups in Indonesia for having a high business ethic. The only question is whether their business ethic due to religious factors, environmental values which forced them to work hard or because of both factors as a result of the dialectical process that eventually forms the Madurese ethnic. Therefore, this true of academic question is to be understood in this study. The object of this study is Madurese ethnic who live in Malang, both from santri and non-santri. The research uses a qualitative approach with a phenomenological and descriptive analysis method. Data mining techniques include observation, interviews, and documentation. The results show that the dialect that has occurred gradually in a relatively long time formed the Madurese ethnic in the city of Malang as a hard worker. It indicates that both santri and nonsantri are not separated because motivated by religious teachings and moral values that exist locally. However, the santri groups seem more motivated by religious teachings compare with non-santri groups which more motivated by local wisdom value.
\end{abstract}

Kata kunci: Etnis Madura, Agama, Kearifan Lokal

Di nusantara ini ada tiga etnis yang dikenal banyak bergelut dalam dunia usaha (bisnis), sekaligus sebagai petualang (perantau), yakni Minang, Madura, dan Bugis. Di berbagai sudut kota hampir dapat dipastikan ditemui sebagian ketiga etnis tersebut, terutama kedua etnis yang pertama. Mereka sangat ulet dalam menekuni sektor informal sehingga kemandiriannya dalam bidang usaha tidak diragukan lagi. Sebab itu, kehadiran mereka dalam sebuah kota akan turut mewarnai aktivitas sektor riil dalam menggerakkan roda perekonomian. Khusus untuk etnis Madura yang menjadi objek penelitian ini tidak sedikit jumlah mereka yang berurbanisasi di Kota Malang, kendati secara statistik jumlahnya tidak diketahui secara pasti. Etos kerja mereka yang sedemikian kuat bisa saja diperoleh secara genetik, atau terpola karena situs sosial-budaya yang melingkupi kehidupan mereka sehari-hari. Atau mungkin pula karena kombinasi keduanya (Triyuwono, 2009). Nampaknya, kerja keras bagi orang Madura merupakan harga mati karena faktor 
geografis daerah asal tidak banyak memberi harapan hidup yang menjanjikan. Karena itu, orang Madura akan sangat marah jika dikatakan sebagai pemalas karena akan menurunkan harga diri di tengah masyarakat.

Menurut sebagian pendapat, semangat kerja keras orang Madura antara lain terdokumendasi dalam peribahasa Madura "abantal omba' asapo' angin" (berbantal ombak dan berselimut angin). Peribahasa ini menyiratkan bahwa orang Madura selama dua puluh empat jam dalam kondisi bekerja dan pantang menyerah. Ini sebagai metafora, dengan bantalnya berupa ombak dan selimutnya berupa angin dengan laut seakan-akan sebagai kantor tempat mereka bekerja, sekaligus sebagai tempat tidur yang penuh tantangan (Bandingkan dengan Triyuwono, 2009; Rifai, 2007).

Di samping mempunyai etos kerja yang tinggi, orang Madura juga dikenal sebagai masyarakat yang religius, kendati bagaimanapun kadar religiusitas masing-masing individu pasti tidak sama antara yang satu dengan yang lain. Namun demikian patut diduga bahwa aspek religiusitas itu bisa menjadi salah satu motivasi untuk bekerja keras guna mendapatkan harta kekayaan sebagai sarana untuk melakukan ibadah kepada Tuhan. Karenanya, tidak heran jika motif pragmatis mereka adalah bahwa dengan bekerja keras, mereka dapat menyempurnakan keislamannya, antara lain bisa menunaikan ibadah haji ke Makkah al-Muakarramah (Bandingkan dengan Triyuwono, 2009; Djakfar, 2009).

Sebagai pekerja keras dan agamis, etnis Madura dikenal pula sebagai komunitas temperamental dan sangat sensitif apabila merasa terusik harga dirinya. Watak keras dan pemberani ini tidak jarang berakhir sampai terjadinya carok antar mereka (Wiyata, 2002; Djakfar, 2009; Rifai, 2007). Namun demikian di sisi lain, sebagai orang yang hidup dalam atmosfer religiusitas, mereka sangatlah patuh kepada ulama (kyai-pemimpin nonformal), melebihi kepatuhannya kepada pemimpin formal sekali pun (Bandingkan dengan Mansurnoor, 1990; dan baca pula Djakfar, 2009).

Sebab itu, semua program pemerintah yang mengabaikan keterlibatan kyai setempat hampir dapat dipastikan tidak akan berakhir dengan sukses sesuai yang direncanakan. Ini disebabkan karena program itu tidak, atau belum mendapat restu dari para kyai sehingga masyarakat berkecenderungan tidak akan memberikan dukungan pula. Ketaatan itu akan semakin kuat jika ada hubungan emosional antara orang Madura dengan mantan kyai yang pernah mendidiknya.

Berdasarkan uraian di atas secara garis besar sebenarnya dalam diri etnis Madura ada dua kekuatan besar, yakni yang bersumber dari adat/tradisi lokal dan nilai agama yang melingkupi kehidupan mereka sehari-hari. Karena itu, pertanyaan krusial yang perlu 
dikedepankan adalah bagaimanakah sejatinya dialektika kedua kekuatan itu dalam membentuk karakter orang Madura di daerah parantauan sehingga mereka dikenal sebagai komunitas yang mempunyai etos bisnis yang tinggi. Problem akademik inilah sebenarnya yang dicoba untuk dipahami dan disajikan dalam laporan penelitian ini.

\section{Pulau Madura: Sekilas tentang Daerah Asal}

Pulau Madura yang menurut tata pemerintahan nasional Indonesia merupakan salah satu wilayah karesidenan (sebelumnya juga disebut wilayah pembantu guberbur, atau sekarang koordinator wilayah) di lingkungan pemerintah propinsi Jawa Timur. Pulau yang dikenal sebagai Pulau Garam ini terletak di timur laut pulau Jawa dengan koordinat sekitar tujuh derajat lintang selatan dan antara 112 dan 114 derajat bujur timur terdiri dari beberapa pulau besar dan kecil. Madura adalah pulau terbesar yang dikelilingi oleh pulaupulau yang lebih kecil, seperti Puteran, Sapudi, Raas, Kangean dan pulau-pulau lain yang lebih kecil yang jumlahnya lebih 100, baik yang berpenghuni maupun yang tidak. Kebanyakan pulau-pulau kecil ini berada di kawasan timur.

Pulau ini merentang dari ujung barat ke ujung timur dengan panjang sekitar $160 \mathrm{~km}$ dan bagian terlebar utara ke selatan kurang lebih 40 km (Rifai, 2007; Djakfar, 229). Luas daratan sekitar 4200 km, sedangkan untuk seluruh wilayah karesidenan kurang lebih 5.168 km2. Panjang daratan untuk seluruh wilayah mencapai sekitar 340 km (Lihat Tim Peneliti, 1994; de Jonge, 1989; Wiyata, 2002).

Pulau yang sekarang sebagai Koordinator Wilayah V ini terbagi atas empat daerah tingakat II (kabupaten). Berturut-turut dari wilayah barat ke timur, yaitu Bangkalan, Sampang, Pamekasan, dan Sumenep. Sebagaimana lazimnya tata pemerintahan di Indonersia, tiap kebupaten tersebut terdiri dari pemerintahan di tingkat kecamatan yang meliputi beberapa pemerintahan desa atau keluruhan. Penguasa di tingkat desa disebut dengan klebun, sedangkan keluruhan dipimpin oleh lurah yang pada biasanya seorang pegawai negeri sipil (PNS).

Di antara gugusan pulau di Nusantara, pulau Madura termasuk daerah yang kering, tandus, tidak hijau, kurang subur. Ini dikarenakan susunan tanahnya yang kurang baik untuk tetumbuhan. Karena pulaunya yang kecil, maka sungai-sungai pendek, pegunungan yang ada berupa bukit kapur dengan ketinggian sekitar $470 \mathrm{~m}$ dari permukaan laut. Pada umumnya bukit-bukit di pedalaman lebih tinggi daripada bukit-bukit di sepanjang pantai. Bukit-bukit di bagian timur lebih tinggi letaknya di atas permukaan air laut daripada di bagian barat Madura. Di barat, bukit-bukit itu jarang mencapai ketinggian 200m. Puncak 
tertinggi di bagian timur Madura adalah gunung Gadu (341m), gunung Marengan (398m), dan gunung Tembuku (471m). Karena kondisi semacam ini nampaknya menjadi salah satu sebab Madura beriklim panas. Suhu udara ketika musim hujan berkisar 28 derajat C dan pada musim kemarau rata-rata 35 derajat $\mathrm{C}$.

Karena pengairan teknis sangat terbatas sekali, tanah pertanian terbesar berupa tegalan, sehingga hasil padi sedikit sekali atau sekitar $23 \%$ dari seluruh hasil tanaman makanan pokok karena hasil terbanyak (sekitar 55\%) adalah ubi kayu. Ini bisa dipahami karena penggunaan tanah untuk persawahan hanya sekitar 9\% saja. Adapun sisanya untuk penggunaan lain seperti perikanan, penggaraman, pemukiman dan lain-lain (de Jonge, 1989; Kuntowijoyo, 2002).

Dengan kondisi geografis yang demikian itu, akhirnya, Madura termasuk daerah miskin di Indonesia. Ini terbukti, pendapatan perkapita penduduk kurang dari sepertiga rata-rata perdapatan perkapita penduduk Indonesia (de Jonge, 1989). Kondisi seperti ini nampaknya hingga saat ini belum banyak mengalami perubahan yang signifikan, sehingga dengan melihat betapa beratnya tekanan sosial ekonomi ini agaknya menjadi salah satu faktor pendorong (push and pull factor) yang memotivasi orang Madura melakukan migrasi ke tempat lain di luar Madura.

\section{Agama dan Etos Kerja}

Dikatakan ada relasi antara agama dan etos kerja. Dalam pengertian "etos" secara umum, negara-negara industri baru (NIC's, Newly Industrializing Countries) di sekeliling Indonesia, katakan saja seperti Korea Selatan, Taiwan, Hong Kong dan Singapura, seringkali dijuluki sebagai "little dragon" (ular-ular kecil). Maksudnya, NIC's adalah rumpun negara-negara penganut ajaran Kong Hucu, dengan ular naga sebagai binatang mitologis dalam sistem kepercayaan mereka (Konfusianis). Dengan kata lain, sebutan itu menunjukkan anggapan bahwa NIC's menjadi maju adalah berkat ajaran atau etika Kong Hucu (filosof Cina). Selanjutnya, kesimpulan pun dibuat bahwa etika Kong Hucu memang relevan, bahkan mendukung, bagi usaha-usaha modernisasi dan pembangunan bangsa industrial (bandingkan dengan Swasono, 2005:216 dan Effendy, 2001).

Cara pandang serupa sebenarnya merupakan penerapan Weberisme atas gejala di luar Eropa Barat, seperti telah banyak dilakukan para pakar. Dalam kaitan ini, Max Weber, sosiolog dan political ecinomist terkemuka asal Jerman, berpendapat bahwa tidak seperti Protestan, khususnya dari sekte Calvinis puritan, Islam tidak mempunyai afinitas teologis dengan perkembangan kapitalisme (Weber, 2003). Bahkan sebagaimana dikutip oleh 
Taufik Abdullah, meskipun dipercaya sebagai agama yang menganut sistem teologi yang "monoteistis universalistis", Islam dianggap sebagai agama kelas prajurit, mempunyai kecenderungan pada kepentingan feodal, berorientasi pada prestise sosial, bersifat sultanistis, dan bersifat patrimonial birokratif, serta tidak mempunyai prasyarat rohaniah bagi pertumbuhan kapitalisme (Abdullah, 1979). Masih menurut Taufik Abdullah, Weber percaya bahwa ajaran Islam mempunyai sikap anti akal dan sangat menentang pengetahuan, terutama pengetahuan teknologi (Abdullah, 1979).

Alasan kuat Werber untuk sampai pada kesimpulan ini adalah dengan melihat praktik-praktik ekonomi kalangan Islam yang tidak mendukung proses pertumbuhan kapitalisme secara keseluruhan. Demikian pula praktik-praktik sufistik Islam yang pada umumnya mengesankan sikap "anti dunia atau melupakan dunia" dijadikan dasar kesimpulan di atas. Lebih lanjut, Weber juga percaya bahwa kalangan Islam- berbeda dengan Protestan-tidak memiliki sikap sederhana, hemat, tekun atau berperhitungan dalam seluruh aktivitas ekonomi. Singkat kata, mereka tidak mempunyai semangat beruf (calling/panggilan ilahi) dan asketis yang mempunyai afinitas dengan pertumbuhan kapitalisme (Effendy, 2001).

Dengan demikian, masih seputar pendapat Weber seperti apa yang dinukil Amin Abdullah, Weber, pernah mempertanyakan dengan nada sinis bahwa agama-agama seperti Islam, Katolik, dan Budha adalah agama-agama yang tidak mendukung proses produksi, atau munculnya kapitalisme awal, karena agama-agama ini merupakan agama yang menyebarkan paham asketik dan hidup membiara, serta agama prajurit, bukan agama kapital (Abdullah, dalam Qodir, 2002).

Sebenarnya tesis Weber itu kurang bisa dipertaggungjawabkan secara realitas, dan bahkan mendapat sanggahan dari berbagai peneliti yang ingin melihat relasi antara agama dan etos kerja. Ketidakakuratan kesimpulan Weber ditengarai karena ia kurang serius dan komprehensif mempelajari Islam, termasuk agama yang lain. Di samping juga Weber bukan saja muncul sebagai anak Eropa yang kagum atas sejarah peradabannya, tetapi juga ia pengikut kecenderungan intelektual dari masa awal orientalisme yang cenderung bias dalam melihat Islam.

Dari kalangan Islam banyak peneliti Indonesia yang membuktikan bahwa tesis Weber tersebut sangat tidak beralasan. Antara lain, Mohammad Sobary (1995) dalam sebuah penelitiannya di Suralaya menyimpulkan bahwa Islam mampu membangun etos kerja atau semangat kapitalisme sebagaimana ajaran Protestan. Samahalnya dengan apa yang dilakukan H. Nanat Fatah Natsir di Tasikmalaya (1999) menyimpulkan bahwa pola 
pemikiran seorang Muslim terhadap etika kerja Islam mengarah pada dua kecenderungan, yakni Qodariyah yang dianut oleh para pengusaha, sedangkan Jabariyah banyak dianut oleh kaum buruh (pekerja).

Zuly Qodir dalam sebuah penelitiannya di Pakajangan, Jawa Tengah (2002), meyimpulkan pula bahwa kerja keras menjadi bagian tak terpisahkan dari masyarakat Pakajangan yang banyak berpaham Muhammadiyah. Bahkan etos ini bukan hanya menjadi sikap mental di kalangan pengusaha atau pedagang, namun juga di kalangan masyarakat luas di sana.

Selain itu, merujuk kepada apa yang pernah ditemukan Clifford Geertz, Zamakhsyari Dhofir menyatakan: "... kehidupan pesantren ditandai oleh suatu tipe etika (etos) dan tingkah laku kehidupan ekonomi yang bersifat agresif, penuh watak kewiraswastaan dan menganut paham 'kebebasan berusaha'. Dari watak tingkah laku ekonomi seperti itulah, menurut pengamatan Geertz, banyak sekali lulusan pesantren yang menjadi pengusaha." (Dhofir, 1982). Dalam hal kegairahan ekonomi di kalangan pribumi atau santri itu, Geertz membuktikan dalam studi antropologisnya pada masyarakat santri "Mojokuto" (Pare, Jawa Timur) yang mempunyai kegairahan ekonomi dan semangat kerja yang sangat kuat (Effendy, 2001).

Keabsahan temuan Geertz akhir-akhir ini semakin diperkuat bukti-bukti nyata semangat ekonomi kalangan pesantren di Indonesia. Di antaranya, secara institusional, bisa dicermati bagaimana perkembangan usaha bisnis di Pondok Pesantren Sidogiri Pasuruan dan An-Nur Bululawang Malang Selatan. Itu semua menunjukkan bahwa agama, dalam hal ini Islam, medorong kepada pemeluknya agar mereka mempunyai semangat untuk mencari harta, antara lain dengan jalan bisnis. Dengan kata lain, ada relasi antara ajaran agama yang transenden dengan aktivitas bisnis dalam upaya untuk memenuhi kebutuhan manusia. Selanjutnya, bagaimanakah peran agama di kalangan masyarakat Madura yang dikenal agamis dalam kaitan dengan etos bisnis sehari-hari. Inilah kiranya yang masih perlu kita gali dan kita pahami dalam penelitian ini.

\section{Kearifan Lokal: Ungkapan Verbal (Parebasan) dan Tradisi (Toron)}

Dalam bahasa Indonesia, kata "arif" dapat diartikan sebagai cerdik, pandai, bijaksana, berilmu (Poerwadarminta, 1986:57), sehingga dengan demikian dalam kehidupan seharhari orang yang arif adalah orang yang bijak dalam melihat dan menghadapi segala sesuatu. Kearifan dengan sendirinya tidak hanya milik personal semata, dalam arti sebagai sebuah 
kekayaan seseorang secara individual. Namun, dalam realitas, bisa lahir dari rahim sebuah komunitas tertentu secara universal yang kemudian dapat dijadikan nilai untuk beraktivitas oleh para anggotanya. Tentu saja, selain ada nilai universal, pasti ada nilai-nilai kearifan yang spesifik dalam komunitas tersebut yang seringkali menjadi karakter sebagai pembeda dengan komunitas lain dalam masyarakat manusia.

Karena itu, bersumber dari kata "arif" itu akhirnya muncul istilah "kearifan lokal" (local wisdom). Dikatakan lokal (locus), karena kearifan itu hanya dimiliki dan diketahui oleh para anggota komunitas tertentu secara internal (insider), untuk kemudian seringkali oleh mereka dijadikan falsafah hidup atau hukum kemasyarakatan dalam interaksi sosial antar sesama dan orang lain. Dan, dengan kearifan itu akan muncul semangat yang bisa menghindari benturan sosial antara yang satu dengan yang lain, baik secara individual maupun secara berkelompok (komunal) dalam masyarakat.

Dalam hubungan dengan semangat ini, ambil saja contoh etnis Madura, Minang, dan Bugis yang dari sisi persamaan, mereka sama-sama dikenal sebagian etnis di Nusantara yang mempunyai etos kerja (dagang) yang militan, selain juga sebagai etnis perantau. Demikian pula etnis Cina, dalam banyak hal banyak persamaan dengan ketiga etnis tersebut. Akan tetapi, perlu disadari, seringkali persamaan nilai-nilai itu diekspresikan oleh masing-masing etnis dalam bentuk kata-kata bijak, petuah, atau adat yang bersifat lokal (kedaerahan/kesukuan) sehingga tidak jarang sulit dipahami oleh orang luar selain mereka sendiri (outsider).

Oleh karena penelitian ini mengambil etnis Madura sebagai objek, maka kearifan lokal yang dimaksud hanyalah sebatas yang bisa digali dari ungkapan verbal (parebasan) sehari-hari atau tradisi yang sedikit banyak masih berpengaruh pada perilaku orang Madura secara umum. Dalam bentuk peribahasa (ungkapan verbal) misalnya, antara lain bagi orang yang malas distigma dengan ungakapan sinis atonggul to'ot (memeluk lutut) dan nampah cangkem (bertopang dagu) (Triyuwono, 2009; Imron, 1996).. Karenanya, ungkapan-ungkapan seperti ini jelas merupakan sikap yang tidak terpuji (Imron, 1996). Untuk itu agar menjadi orang terhormat hendaknya orang Madura harus bilet (ulet) dan junel (berkewiraushaan) (Rifai, 2007).

Dalam sebuah larik "Pingpilu" ada sebuah sindiran yang berbunyi: "Pingpilu, $t a^{\prime}$ endha"' nyempang lorongah. Pingpilu, lorongngah tombuwi janggel. Pingpilu, ta'endha' ngala' toronna. Pingpilu, toronna oreng ta' bajeng." D. Zazawi Imron menafsirkan larik ini bahwa orang Madura lama tidak mau menerima keturunan orang yang tidak rajin dan tak becus bekerja. Karena itu, memahami makna di balik larik ini dapat disimpulkan 
bahwa kapan pun saja: dulu, sekarang dan seterusnya, orang Madura harus mempunyai semangat kerja untuk mencari rezeki. Terlebih lagi, bagi mereka yang sudah berstatus sebagai suami yang harus menaggung nafkah anak dan istri, agar tidak terkenal ungkapan sinis ja' gun karo abandha peller (jangan hanya bermodalkan kemaluan saja). Karena itu, tiada hari tanpa semangat kerja dalam keadaan apa pun sebagaimna tersirat dalam sebuah ungkapan metaforik yang berbunyi: "abantal omba' aspo' angin." Artinya, berbantal ombak berselimut angin, sebuah spirit yang pada kenyataannya tidak terbatas kelautan saja, tapi juga pada enerjisitas kehidupan pada umumnya.

Tapi laut agaknya memang hampir tak terelakkan dalam kehidupan orang Madura sehingga pucuk rumah Madura pun dibuat menyangga perahu, kendaraan utama dalam mencari rezeki Allah di perut laut, sekaligus sarana untuk menjangkau negeri-negeri yang jauh (Imron, 1996; Djakfar, 2009). Selain dalam bentuk ungkapan, di kalangan masyarakat Madura dikenal istilah pulang kampung (mudik-toron), sebagai kebalikan dari istilah onggha (ke luar Madura). Toron ini merupakan tradisi lokal yang penuh makna bagi masyarakat Madura pada umumnya yang telah bertekad merantau ke negeri orang.

Etnis Madura yang bermigrasi di tanah rantau tetap memiliki ikatan emosional dengan daerah asal (patobin) dan dengan kerabat (balah kerabah) di kampung halaman. Mereka masih menjalin komunikasi yang intensif dan berkseinambungan tentang berbagai hal di daerah asal. Hal ini terbukti, bahwa pada momen tertentu seperti acara perkawinan, acara pemberangkatan haji keluarga, peristiwa kematian kerabat, hari raya 'idayn, hari-hari besar Islam, acara berziarah ke makam leluhur dan kedua orangtua, dan lain sebagainya, mereka masih menyempatkan diri sambil pulang kampung (toron) (Bandingkan dengan Subaharianto, 2004).

Bahkan tidak jarang untuk urusan makam orangtua dan leluhur, mereka mencoba terus merawatnya dengan cara membangun kuburannya (ngejing) sebagai simbol bakti anak kepada orangtua yang merupakan implementasi dari filosofi bappa', bhabbu', ghuru, ratho. Lebih jauh implementasi filosofi ini pula, di kalangan komunitas pesantren, sebagai simbol rasa hormat (ta'dhim/ngagungagi) kepada mantan kyai, para santri tetap melakukan silaturrahim, memondokkan anak ke bekas almamater (santre toronan) dan bahkan seringkali pula mereka ikut berpartisipasi membantu bangunan fisik untuk pengembangan pondok pesantrennya.

Hanya saja perlu dipahami, bahwa toron bagi orang Madura tidak sekadar pulang kampung, tetapi ada unsur pamer (unjuk keberhasilan) kepada para keluarga, tetangga, dan masyarakat sekitar yang menunjukkan bahwa seseorang merantau jauh dari kampung 
halaman tidaklah sia-sia. Baragamnya oleh-oleh yang dibawa pulang dan tampilan diri (performan) dengan sendirinya akan mengangkat harga diri dan akan dipuji oleh masyarakat lingkungannya. Karena oleh-oleh dan tampilan itu sebagai simbol keberhasilan bisnis yang mengandung makna keberhasilan meningkatkan kualitas hidup di luar kampung halaman.

Dengan adanya makna toron yang demikian itu, maka bagaimanapun orang Madura yang merantau harus bekerja keras banting tulang agar kuat dalam ekonomi. Apabila tidak, bukanlah tidak mungkin akan menjadi gunjingan orang dengan ucapan: $m a^{\prime}$ uja-wu nyare kasab, alako e Madhura kan la padha bai (untuk apa jauh-jauh cari kerja, kan kerja di Madura sama saja). Maksudnya, jika hasilnya sama dan tidak akan merubah nasib, maka tidak perlu merantau ke negeri jauh. Itulah tantangan bagi para perantau Madura, agar berhasil di negeri orang.

\section{METODE}

Sesuai dengan tema yang telah dirumuskan, maka tujuan yang ingin diraih dalam penelitian ini adalah untuk memahami secara mendalam bagaimanakah agama berdialektika dengan kearifan lokal (local wisdom) yang tercermin dalam etos bisnis etnis Madura yang banyak merantau di Kota Malang.

Dengan demikian penelitian ini termasuk dalam kategori penelitian kualitatif dengan analisis deskriptif, yakni metode yang menfokuskan perhatiannya pada prinsipprinsip umum yang mendasari satuan-satuan yang berkaitan dengan tema penelitian. Etnis Madura dipilih sebagai sasaran penelitian atas dasar pertimbangan karena selain jumlah mereka cukup signifikan, juga dikenal sebagai pelaku bisnis yang ulet tanpa mengenal menyerah. Karena itu perlu dipahami apa motif keuletan itu, apakah karena faktor tradisi lokal atau lingkungan, atau karena faktor nilai agama yang menjadi muatan keyakinan mereka. Ataukah karena akumulasi dari kedua faktor tersebut.

Untuk itu, untuk memahami semuanya itu ditetapkanlah metode fenomenologi, yakni metode untuk memahami bagaimana tata cara masyarakat, kebudayaan, dan pribadipribadi mempengaruhi agama, sebagaimana agama itu sendiri mempengaruhi mereka (Syamsuddin, 2001). Dengan pendekatan fenomenologis, sebuah penelitian tidak hanya akan menghasilkan suatu deskripsi mengenai fenomena yang dipelajari, dalam hal ini yang berkaitan dengan etos bisnis etnis Madura sebagaimana yang sering diperkirakan. Dan, tidak pula bermaksud menerangkan hakikat filosofis dari fenomena objek itu, sebab fenomenologi agama bukanlah deskripsi atau normatif semata. Namun, dunia konseptual, 
stok pengetahuan (pemahaman), dunia kesadaran para pelaku ditempatkan sebagai kata kunci untuk bisa memahami tindakan manusia, kapan pun dan di mana pun saja (Bandingkan dengan Bungin, 2003). Dalam arti, metode ini memberikan kepada kita, arti yang lebih mendalam dari suatu fenomena religius, sebagaimana dihayati dan dialami oleh manusia-manusia beragama (Syamsuddin, 2001), seperti di kalangan etnis Madura di Kota Malang.

Oleh karena asumsi dasar dari pendekatan ini adalah bentuk luar dari ungkapan manusia yang mempunyai pola konfigurasi dalam yang teratur, yang dapat dilukiskan kerangkanya dengan menggunakan metode fenomenologi (Dhavamony, 1945), maka peneliti ingin mencoba dan mengangkat serta memahami setiap ungkapan verbal maupun aktivitas yang berkaitan dengan motif objek penelitian dalam melakukan bisnis.

Adapun teknik pengumpulan data menggunakan observasi, wawancara dan dokumentasi. Hanya saja yang paling pokok adalah teknik yang kedua, yakni wawancara guna mengungkap motif-motif etos bisnis yang membentuk etnis Madura. Sedangkan observasi sebatas untuk mengamati aktivitas bisnis dalam realitas yang diperkuat pula dengan pencatatan data yang telah terdokumentasi yang terkait dengan penelitian. Sedangkan informan yang dijadikan sumber data adalah para pedagang perantauan dari etnis Madura di Kota Malang dengan menggunakan teknik snowball sampling sesuai kebutuhan agar lebih alami dan objektif dalam mamahmi motif-motif di kalangan mareka sesuai dengan tujuan penelitian.

\section{HASIL DAN PEMBAHASAN}

Sebagaimana tertera dalam judul, penelitian ini mengambil Kota Malang sebagai situs penelitian yang menjadi salah satu sasaran urbanisasi etnis Madura yang dikenal sebagai salah satu etnis perantau. Sebagai kota besar kedua di Jawa Timur, Kota Malang memang menyimpan banyak potensi yang secara langsung atau tidak bisa menjadi pemicu percepatan (akselerasi) perkembangan ekonomi. Potensi tersebut, antara lain bisa dicermati dari ketersediaan sumber daya alam (natural resources), kemampuan dan ketersediaan sumber daya manusia (human resources), dan kemampuan di bidang potensi ekonomi (Humas KKM, 1998). Berdasarkan sumber data Biro Pusat Statistik (BPS) Kota Malang, kota ini sekarang dihuni oleh 816.637 ribu orang, terdiri dari 404.664 (laki-laki) dan 411.973 ribu (perempuan) yang menempati di lima wilayah kecamatan, terdiri dari 57 kelurahan (BPS Kota Malang dalam Angka 2009). 
Berdasarkan keterangan dari orang Madura yang telah lama menetap di Malang, antara H. Faisal Hadrawi, H. Djazuli, H. Adum Dasuki, H. Abd Hadi, dan H. Yusuf, yang diperkuat oleh staf Pemerintah Kota Malang, dari kelima wilayah kecamatan tersebut, etnis Madura banyak terkonsentrasi di kecamatan Kadungkandang dan Blimbing. Terutama di kelurahan Kedungkandang, Mergosono, dan Kotalama. Selain juga di kelurahan Polehan dan Jodipan. Mereka banyak terkonsenrasi di kelima kelurahan ini menurut pengamatan peneliti karena kelimanya relatif dekat dengan pusat kegiatan bisnis kota, yakni Pasar Besar dan Pasar Induk Gadang.

Kedudukan geografis baik dalam konteks regional Jawa Timur maupun dalam pengembangan wilayah Kota Malang sendiri, kota ini memiliki potensi yang cukup besar oleh karena sebagai daerah pegunungan tanahnya subur, pusat pertanian dan wisata, pusat industri dan pendidikan (Djakfar, 2009). Di Kota Malang, pertambahan jumlah penduduk tidak hanya karena faktor kelahiran, akan tetapi juga karena pesatnya urbanisasi (Bapedalda, 2004), termasuk dari etnis Madura. Demikian pula dari aspek kualitas sumber daya insani, Kota Malang sebagai kota pendidikan berpotensi bisa memanfaatkan jasa para pakar dari berbagai perguruan tinggi yang ada sesuai dengan bidang yang diperlukan (BAPEKO Pemerintah Kota Malang, 2004).

Sekadar gambaran berkaitan dengan masalah pendidikan, di kota ini terdapat 50 perguruan tinggi negeri dan swasta, termasuk lembaga pendidikan setara Diploma serta pendidikan Taman Kanak-Kanak (TK) hingga menengah atas mencapai kurang lebih 800 lembaga. Selain adanya berbagai macam lembaga kursus dengan berbagai ragamnya jumlahnya berkisar 240 buah (Djakfar, 2009). Besarnya potensi ini tentu saja berpotensi sebanyaknya peredaran uang yang masuk ke Kota Malang yang pada akhirnya berpotensi pula menggairahkan sektor riil. Di samping itu Kota Malang memiliki sejumlah industri andalan seperti pabrik rokok, kompor, koroseri, home industri dengan berbagai ragamnya seperti kerajinan keramik, onix, tempe, tasbih, raket, shuttle cock, sanitair, sangkar burung, saos tomat, dan lain-lain (Djakfar, 2009).

Industri lain yang tidak kalah pentingnya adalah pariwisata. Pariwisata yang dimaksud adalah pariwisata yang berbasis alami, seperti Sengkaling, Tlogomas, Selecta, Coban Rondo, Coban Talun, Cangar, Wendit, Gunung Bromo, Lembah Dieng, Sendang Biru dan lain-lain, kendati di antaranya itu berada di luar Kota Malang. Walau pun demikian, Kota Malang juga masih menyimpan aset wisata berbasis perkotaan peninggalan situs sejarah, seperti Toko "OEN", Perumahan di kawasan Ijen (Ijen Boulevard). Temasuk tempat-tempat ibadah yang juga menjadi objek wisata yang karena usianya yang cukup tua, 
seperti Masjid Agung Jamik, Gereja Jl. Ijen, dan Jl. Basuki Rahmat, Pura Hindu di Gunung Buring dan Klenteng Kong Hu Chu Tri Dharma (Djakfar, 2009).

Karena keterbatasan objek wisata alam, menempatkan sarana pertokoan, seperti pertokoan Mitra, Ramayana, Gajahmada, Malang Plaza, Dieng Plaza, MATOS, MOG, pertokoan Pecinan, dan Pasar Besar mempunyai daya tarik tersendiri. Semua ini tentu saja akan menjadi daya megnetik bagi wisatawan untuk dijadikan wisata ekonomi. Demikian pula halnya keberadaan taman kota, alun-alun, balai kota (Tugu), museum, wisata pasar minggu pagi di stadion Gajayana dan lain-lain memiliki daya pikat pula bagi para pengunjung.

Demikian pula dalam hubungannya dengan potensi ekonomi yang lain dan daya dukung yang ada, sebagai daerah yang berperan sebagai pengatur arus barang dan jasa, maka Kota Malang mengalami pertumbuhan ekonomi yang cukup pesat. Dalam hal ini antara lain bisa dibaca dari pendapatan perkapita penduduk yang semakin meningkat dari tahun ke tahun. Berbagai daya dukung yang bisa ikut memacu percepatan ekonomi dan bisnis Kota Malang, antara lain bisa dipahami bahwa karena berbagai potensi yang ada tersebut, di kawasabn Jawa Timur, nampaknya Kota Malang telah lama ditetapkan sebagai salah satu pusat pengembangan wilayah dataran tinggi tengah Jawa Timur (lihat Bagian Humas KKM, 1998).

Berdasarkan daya dukung dan potensi ekonomi tersebut sangatlah wajar apabila Kota Malang menjadi sasaran urbanisasi berbagai etnis di Indonesia, di mana etnis Madura termasuk di dalamnya. Adanya daya dukung dan potensi ekonomi jelas akan banyak memberi harapan dalam aktivitas bisnis apa pun saja. Karena dengan potensi itu bisnis akan mudah berkembang, dan dengan daya dukung yang ada aktivitas bisnis akan lebih kondusif untuk ditekuni.

\section{Kerja Keras: Simbol Pertaruhan Harga Diri}

Etnis Madura dikenal sebagai manusia sensitif dalam hal mempertahankan harga diri. Peristiwa carok yang seringkali mengorbankan nyawa pada hakikatnya adalah karena bersentuhan dengan harga diri masing-masing pihak yang terlibat, baik secara individu maupun komunal (kelompok). Etos kerja yang tinggi di kalangan mereka dapat disebabkan oleh banyak faktor, antara lain adalah karena "harga diri," sebagaimana dapat dipahami dari pepatah (parebasan) "etembang noro' oreng, ango'an alako dhibi' make lane'kene'." (lihat Triyuwono, 2009). Artinya, daripada ikut orang lain lebih baik bekerja (usaha) sendiri walaupun hanya kecil-kecilan. 
Memang sebagian besar mereka mengakui bahwa bantuan orang lain, terutama keluarga dekat sangat diperlukan. Tanpa bantuan mereka, sulit rasanya untuk bisa memahami kiat-kiat sebuah aktivitas bisnis, khususnya bagi pemula yang baru belajar dalam berbisnis (adagang). Akan tetapi menurut mereka bantuan itu jangan sampai berketerusan yang pada akhirnya akan menjadi beban orang lain. Menjadi beban orang lain itu dianggap enah (aib) dan dianggap tidak mempunyai harga diri. Apalagi bagi orang yang sudah berkeluarga. Demikian pengakuan H.Yusuf, H.Abd.Hadi, Nasab, H.Syahid, Hj.Fauzah, Bang Imam, dan yang lainnya.

Oleh karena itu, kemandirian dalam bekerja merupakan sebuah kehormatan. Orang Madura lebih memilih bekerja sendiri (mandiri) di bidang apapun asalkan memperoleh hasil, sekalipun hanya sedikit. Asal saja halal dan barokah. Betapa kuat semangat orang Madura untuk hidup mandiri dan bekerja apa saja asalkan menghasilkan, nampaknya memperkuat penilaian H.Afif Hasan (tokoh muda Madura dan pebisnis konveksi) yang menyatakan bahwa antara etnis Madura dan Cina, sekalipun pada keduanya ada titik persamaan, yakni pekerja keras dan ulet, namun ada perbedaan. Antara lain, "orang Madura mencari kerja", sedangkan "orang Cina mencari uang." Ini mengandung makna bahwa dalam bekerja, orang Madura tidak begitu mempermasalahkan hasil yang besar. Sebaliknya, yang dikejar etnis Cina, justru hasil yang besar yang menjadi ukuran target kepuasannya. Sikap semacam itu nampaknya merupakan ekspresi dari ungkapan karkarkar colpe' yang berarti bagaikan seekor ayam yang sedang mencakar-cakar tanah untuk menemukan sesuatu untuk dimakan meskipun mungkin hanya sedikit, akan tetapi dilakukan dengan penuh kesabaran (Syamsuddin, 2001; Tidjani, 1996).

Sehubungan dengan harga diri orang Madura yang ikut mendorong mereka harus bekerja keras di rantau orang banyak terkait juga dengan penilaian masyarakat pada saat mereka toron (pulang kampung). Dalam hal ini bisa dipahami penuturan M. Ali Nuryadi, mantan kepala Pasar Induk Gadang sebagai-berikut:

"Bisa dibayangkan, menurut mereka (orang Madura-pen) jika pulang ke kampung halaman di Madura harus membawa oleh-oleh yang banyak. Meja di rumah diharapkan penuh dengan berbagai makanan untuk menjamu para keluarga dan tetangga teparo yang menyambut kedatangan mereka. Jika tidak, mereka rasanya malu untuk pulang (toron) karena akan menimbulkan kesan negatif bahwa seseorang belum berhasil merubah nasib di rantau orang. Nampaknya, penilaian negatif seperti itulah yang diantisipasi oleh setiap orang Madura agar harga dirinya tetap bisa dipertahankan di hadapan masyarakat. Cara yang harus dilakukan adalah dengan kerja keras." 
Pada dasarnya harga diri dan martabat merupakan nilai yang sangat erat dan mendasar sekali bagi masyarakat Madura dan selalu harus dipertaruhkan. Motivasinya adalah rasa malu (malo atau todus). Bahkan ada ungkapan yang banyak dinyatakan "tambana todus mate," yang artinya obatnya malu adalah mati" (Tidjani,1996). Rasa malu di sini juga menyangkut masalah dunia kerja, sehingga jika sekiranya gagal dalam bisnis, mereka akan merasa aib kepada lingkungannya.

Sebagaimana telah disinggung sebelum ini, bahwa harga diri itu di kalangan etnis Madura menempati wilayah sensitif yang sangat dijunjung tinggi dan tidak boleh diaganggu oleh siapa pun saja. Sebagaimana tersirat dalam filosofi yang sangat populer: tembhang apote matah bhengok apote tolang (dari pada putih mata lebih baik putih tulang). Maksudnya, daripada hidup menaggung malu, lebih baik mati berkalang tanah. Berbagai hal yang termasuk dalam wilayah kehormatan dan harga diri adalah keluarga, istri dan anak-anak, harta dan sandang pangan (lapangan pekerjaan/bisnis) (Nilam, 1996). Abdul Latif Bustami memaknai arti parebasan di atas, sebagai pembelaan kepentingan politik harga diri dan ekonomi (Bustami, 1996; Wiyata, 1996). Sebab itu, demi melindungi harga dirinya, etnis Madura berani bekerja sekuat tenaga dan mandiri agar ekonominya menjadi kuat sehingga akan merasa terhormat di mata masyarakat lingkungnnya.

Dalam kenyataan harga diri yang menyulut kerja keras itu etnis Madura di Kota Malang mampu menguasai kedua pasar tradisional yang menjadi simbol mobilitas perekonomian kota, yakni Pasar Besar (PB) dan Pasar Induk Gadang (PIG). Padahal mereka adalah pendatang dan banyak pesaing dengan etnis lain, terutama etnis setempat (Jawa). Dalam hal ini, Sulistiono (pedagang di PB, asal Bantur) menuturkan:

"Kalau perkiraan saya, mungkin jumlah pedagang etnis Madura di PB ini lebih dari $65 \%$. Hal ini bisa dilihat dan dibuktikan para pedagang di lantai satu dan dua pasar ini yang banyak adalah etnis Madura. Saya melihat etnis Madura orangnya sangat ulet dan tidak mengenal gengsi. Artinya, kerja apa saja yang penting halal dan menghasilkan uang. Lain halnya dengan etnis Jawa yang menurut saya tidak seulet etnis Madura. Etnis Jawa seringkali masih mempunyai rasa gengsi dan tidak mau kerja apa saja seperti etnis Madura. Mereka lebih banyak memilih kerja kantoran atau pabrikan, sekali pun hasilnya ya juga terbatas."

Pernyataan Sulistiono itu sejalan dengan pendapat Eko Sya (mantan kepala PB) yang menyatakan bahwa PB memang didominasi oleh etnis Madura yang pendatang. Bahkan berdasarkan pengakuan Nuryadi dan Ilham (sama-sama mantan kepala PIG), dominasi etnis Madura di PIG ini jauh lebih besar lagi yang diperkirakan kurang lebih $86 \%$ dari jumlah pedagang yang ada. Hal ini mengandung makna bahwa pasar merupakan "simbol etos kerja etnis Madura" sebagai pengejawantahan dan pertaruhan dari rasa 
mempertahankan rasa harga diri di tengah masyarakat, terutama dalam lingkungan mereka sendiri.

Hal lain yang perlu dipahami, kerja keras (kebrentengan) di kalangan etnis Madura perantauan di Kota Malang tidak mengenal bias gender. Artinya, antara lelaki dan perempuan tidak ada perbedaan dalam mencari nafkah di rantau orang. Suami dan istri dalam sebuah keluarga saling bahu-membahu menekuni bisnis yang telah menjadi pilihan hidupnya.

\section{Motif dalam Bisnis: Memahami Dilektika antara Agama dan Karifan Lokal}

Di tengah ketat dan kerasnya persaingan dunia kerja saat ini rasanya tidaklah semua kalangan masyarakat mampu merebut pekerjaan sektor formal. Apalagi dengan keterbatasan kemampuan (pengetahuan dan skill) yang dimiliki, memaksa sebagian dari mereka harus terjun ke dalam sektor kerja informal, antara lain sebagai pedagang kaki lima (Humas KKM, 1998). Terlebih lagi pekerjaan sektor ini tidak banyak menuntut potensi diri dan legalitas formal sebagaimana sektor formal. Karena itu, menurut pandangan mereka, tanpa kecuali dari etnis Madura, sektor informal dianggap paling tepat untuk ditekuni guna menjamin kelangsungan hidupnya.

Apabila dicermati secara teliti faktor apa saja yuang memotivasi kebiasaan kerja keras etnis Madura di Kota Malang. Menurut pengakuan Halima (63 tahun), asal Larangan (Tlanakan) Pamekasan bersama suaminya menekuni bisnis buah sekitar 30 tahun menuturkan "kadi panapa pak badana Madhurah kadi ka'esah, ta' bisa egabai gercager, enggi se sae ma'le odi' sae, kodhu kalowar Madhurah" (bagaimana ya pak, keaadaan Madura yang seperti itu tidak bisa diandalkan, agar bisa hidup lebih baik, ya harus ke luar Madura).

Sejalan dengan pernyataan Halima, Sunar, seorang asal Burneh Bangkalan, bersama adiknya, Ari, menyatakan "kadi napa pak badha neng Madhurah, kan karo ataneh ne'kene' kaangguy ngakan, ta' bisa melle klambi. Melana, kaula ka Malang daddi tokang cokor mulai taon 1995 abareng ale"' (bagaimana pak kalau tinggal di Madura kan hanya bertani kecil-kecilan, tak bisa beli baju, makanya saya merantau ke Malang sejak tahun 1995 ditemani adik). Kedua kakak beradik yang mengaku lulusan SMA, yang pernah magang di Suabaya selama dua tahun (sebagai tukang cukur) akhirnya berupaya mandiri merantau ke Malang. Alasannya cukup klasik, sulit cari kerja, sehingga sejak di bangku sekolah ia sudah mulai belajar mencukur, terpengaruh lingkungannya yang sebagian besar berprofesi sebagai tukang cukur. 
Di Malang, mereka berdua harus kerja keras agar sukses dan bisa bertahan hidup, tidak menjadi beban keluarga, bahkan agar bertanggung jawab dalam keluarga. Ternyata usaha Sunar berdua membuahkan hasil, dari hasil profesinya itu (rata-rata perhari melayani antara 30-40 pelanggan), ia dan adiknya telah memiliki rumah tinggal sendiri di kawasan kelurahan Mojolangu. Adapun yang memacu dirinya mencari kasab (kerja) di rantau orang, sebagaimana masyarakat daerah asalnya (Burneh), adalah agar bisa merubah nasib dalam hidup. Tidak nunggu dan pasif (atonggul to'ot dan nampa cangkem) di Madura yang tidak menghasilkan apa-apa dari hasil pertanian di sana.

Demikian pula, H. Rosyidi (nama asal Ahmad Razak) yang telah menunaikan haji tahun 2006 hasil bisnis kacang dan mente goreng selama kurang lebih 35 tahun di Kota Malang. Rosyidi yang mengaku tidak bisa baca tulis karena hanya mengalami kelas satu SD di daerahnya, yakni Kramat (Tlanakan-Pamekasan), sejak masih anak-anak merantau ikut pamannya berjualan jajan. Setelah merasa mampu ia mandiri, kendati belum berkeluarga. Setelah berkeluarga ia terus melanjutkan bisnis kacang goreng sebagai rasa tanggung jawab sebagai kepala keluarga: "kaula tanggung jawab, ta' poron ekoca gun ngeba peller dalem akalowarga" (saya bertanggung jawab, tak mau dikatakan tidak bawa apa-apa dalam keluarga). "Melana kaula alako onggu-onggu sanaosah ne'kene,' se penting hasel tor halal, enggi karo ajuwalan kacang sareng embu'en ana'" (makanya saya bekerja sungguh-sungguh, sekali pun kecil-kecilan, yang penting punya untung dan halal, ya hanya berjualan kacang seperti ini didukung ibunya anak-anak). "Mon ta' hasel kan todus pak manabi toron, kan pas esanggu ta' tanggung jawab" (kalau tidak berhasil kan malu pak kalau pulang kampung, nanti dikira tak bersungguh-sungguh dan tak tanggung jawab). Hanya dengan penghasilan bersih rata 100 ribu rupiah perhari, ia mampu menghidupi istri dengan ketiga anaknya.

Pada dasarnya tidak beda dengan penuturan H. Khoiruddin (asal Taro'an Pamekasan) bersama istrinya yang asli Pakong sudah 14 tahun menekuni bisnis konveksi di Pasar Besar. Demikian pula halnya keluarga Ahmadi beserta istri, adiknya, yakni Bachri dan Ahmad Suyono, telah 15 tahun menekuni bisnis buah mobil, dan baru dua tahun terakhir berjualan menetap di kawasan Soekarno-Hatta. Kedua keluarga ini sama-sama merasa tidak mungkin hidup makmur di Madura, sehingga harus hijrah ke luar dengan kerja keras (pettel-brenteng-bilet), mandiri secara ekonomi (junel-dalam usaha) agar tidak merasa hina (enah-astabah) pada lingkungan tetangga.

Pada dasarnya di antara mereka itu ada rasa persaingan terselubung, sehingga masing-masing harus berhasil, dan keberhasilan itu ditunjukkan tidak saja di daerah rantau, 
bahkan juga ketika mereka pulang kampung (toron). Tujuannya adalah untuk mengangkat harga diri, baik secara individual maupun kelompok (keluarga). Sebagai komunitas yang berasal dari daerah yang agamis, mereka menyadari bahwa dengan bekerja itu, selebihnya dari biaya kebutuhan sehari-hari, diharapkan kelak bisa digunakan untuk menunaikan ibadah haji sebagai kewajiban syariat.

Dengan demikian pada prinsipnya motif mencari nafkah yang terpokok adalah karena tuntunan lingkungan (kultur) dan karena kondisi geografis yang tidak banyak menjanjikan. Selain juga secara tidak langsung karena dorongan untuk menunaikan kewajiban agama seperti haji sebagaimana dialami keluarga H. Khoiruddin dan H. Rosyidi.

Tidak demikian motif-motif etnis Madura yang lebih kental jiwa santrinya, seperti H.Ahmadi, H.Arif dan Hj.Fauzah yang secara kebetulan menekuni bisnis jagal (jual daging). Ahmadi (asli Buker Jrengik Sampang) dan Arif (asli Torjun Sampang), keduanya berada di kawasan Mergosono, pernah mondok di pesantren Assirojiyah Sampang, masingmasing alumi tahun 1975 dan 1979. Sedangkan Hj. Fauzah (di kawasan Klojen) yang pernah menimba ilmu ekonomi di Fakultas Ekonomi Universitas Brawijaya Malang, adalah keluarga santri tulen, H. Rifa'i dari Sampang. Pada dasarnya mereka menuturkan bahwa motif bekerja yang pokok adalah untuk ibadah, karena dengan niat seperti itu rezeki itu akan datang dengan sendirinya. "Kan se pokok pak ebadha, soal rejekke, asal ampon usaha onggu maste dateng dhibi' (kan yang pokok itu niat ibadah, kalau soal rejeki asal kerja kelas pasti akan datang dengan sendirinya).

Selain itu mereka sepaham, bagaimana pun orang Madura, sebagaimana juga orang lain, harus berupaya mandiri agar tidak menjadi beban orang lain. "Manabi ta' alako onggu-onggu kan ta'sae, pas bila se haselah, panapa pole odi' neng manca, pas ta' hasel kan todus da' tatanggah" (kalau tidak bekerja sungguh-sungguh, kan tidak baik, kapan bisa berhasil, apalagi hidup di tempat jauh, kalau tidak berhasil kan malu pada tetangga). "Kan sapaneka pa' koduna se biasa monggu oreng Madhurah" (kan begitu pak semestinya yang umum bagi orang Madura).

Dari kedua kelompok informan tersebut dapat dipahami bahwa dari kalangan santri, motif utama bekerja keras dalam mencari nafkah adalah sebagai bagian dari ibadah (ghairu mahdhah), selain juga karena faktor tradisi (lingkungan) yang turut mendorong. Sedangkan dari kalangan nonsantri, sebaliknya, lingkunganlah (tradisi) yang sangat dominan, kendati faktor agama juga masih turut memacu.

Dengan demikian, di kalangan etnis Madura perantauan telah terjadi dialektika antara agama dan kearifan lokal, kendati dalam realitas kedua faktor ini nampaknya tidak 
sama mana yang paling dominan di antara kedua kelompok informan. Agama dan kearifan lokal (tradisi) saling berdialektika, karena di tempat asalnya, yakni Madura, keduanya merupakan entitas yang sama-sama dijadikan norma yang dapat membentuk karakter orang Madura di mana pun mereka berada. Bahkan di rantau sekali pun.

Untuk jelasnya, bagaimanakah gambaran dialektika di antara kedua kelompok tersebut, dapat dicermati pada visualisasi 1, 2, dan 3 berikut ini.

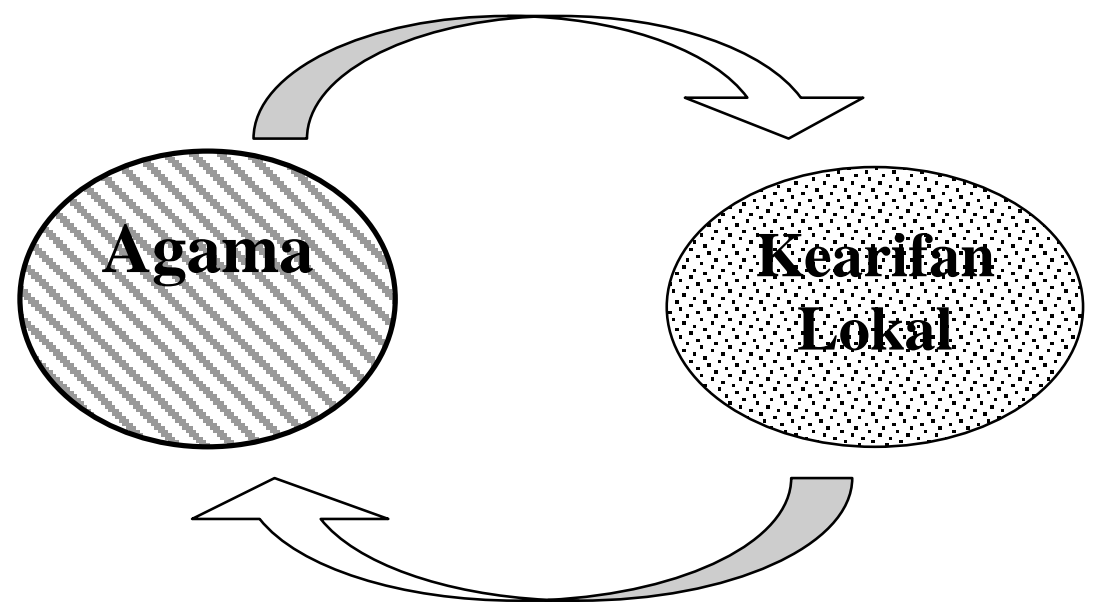

Visualisasi 1. Dialektika Agama dengan Kearifan Lokal

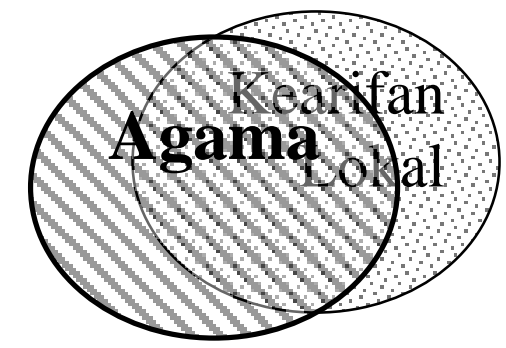

Visualisasi 2. Motivasi Etos Bisnis Kaum Santri

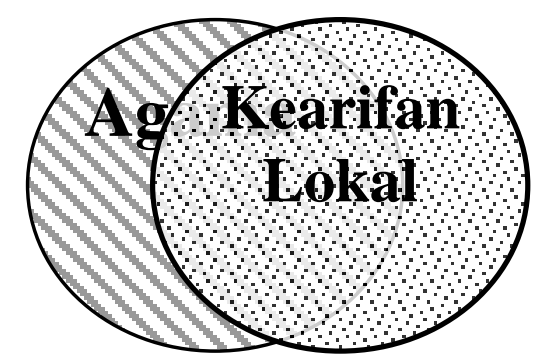

Visualisasi 3. Motivasi Etos Bisnis Kaum Non Santri 


\section{KESIMPULAN}

Bertolak dari paparan dan analisis hasil di atas dapat dipahami bahwa ternyata etnis Madura perantauan di Kota Malang benar-benar mempunyai etos bisnis yang sangat tinggi dan mereka mampu berkompetisi dengan etnis lain sesama pebisnis di kota ini. Jika dikatakan bahwa orang Madura pada umumnya "mencari kerja (nyare lako), bukan sekadar mencari hasil" dapat dimaknai bahwa mereka siap kerja apa saja, asalkan mendatangkan hasil. Bagi mereka, berapa hasil secara kuantitas yang akan diperoleh, nampaknya tidaklah menjadi pertimbangan utama, karena yang paling pokok menurut mereka adalah mempunyai penghasilan sebagai syarat untuk menyambung hidup diri dan keluarganya. Sebab itu, dengan bermodalkan prinsip seperti inilah, dalam kenyataan mereka berani memasuki berbagai ragam bisnis apa saja, terutama di sektor informal yang tidak, atau jarang dilakukan etnis lain.

Dilihat dari informan, dalam penelitian ini, secara tegas dapat diklasifikasi ke dalam dua komunitas, yakni yang berlatar belakang santri dan yang nonsantri. Yang berlatar belakang santri, motivasi mereka dalam bekerja lebih disebabkan karena faktor agama sebagai bagian dari ibadah kepada Tuhan. Selain juga karena faktor lingkungan (sosiologis-adat-tradisi) yang mendorong agar siapa pun sebagai orang Madura, harus bekerja keras (nyare engon) untuk diri dan keluarganya. Jika tidak, masyarakat akan menstigma sebagai pemalas (atonggul to'ot), tidak cakap ( $t a^{\prime}$ brenteng, ta' pettel, ta'bilet), kawin hanya bermodalkan alat kemaluan (gun abandha peller), dan kata-kata lain yang bisa menurunkan rasa harga diri.

Sebaliknya, dari kalangan nonsantri dapat dipahami mereka lebih termotivasi karena tradisi orang Madura yang beretos kerja tinggi sehingga akhirnya mereka berani merantau ke luar Madura, antara lain ke kota Malang. Motivasi kerja sebagai ibadah, nampaknya terimbas karena faktor milieu yang dikenal agamis sebagaimana karakter masyarakat Madura pada umumnya. Dari motivasi kedua kelompok informan di atas dapat dipahami, bahwa yang mendorong etos bisnis etnis Madura perantauan di kota Malang, tidak semata karena faktor agama, namun juga karena berbagai faktor yang sudah menjadi filosofi dan tradisi masyarakat Madura secara turun-temurun. Filosofi dan tradisi inilah kiranya yang dapat disebut sebagai kearifan lokal (local wisdom).

Nilai-nilai agama dan kearifan lokal yang telah ber-simbiose mutualistis itu tentu saja sudah sedemikian lama dijadikan nilai dalam kehidupan di kalangan mereka. Keduanya telah saling mengisi dan berdialektika secara gradual dalam membentuk pribadi etnis Madura pada umumnya, antara lain dapat dipahami dari bagaimana cara mereka 
melakukan bisnis. Nilai-nilai hasil dialektika itu terus berinteraksi dalam diri orang Madura, di manapun mereka hidup dan melakukan berbagai aktivitas. Tanpa kecuali dalam aktivitas bisnis.

\section{DAFTAR PUSTAKA}

Abdullah, Amin, 2002, "Agama dan Kesalehan Sosial Pengusaha Muslim," dalam Zuly Qodir, Agama \& Etos Dagang, Solo: Pondok Edukasi

Abdullah, Taufik , (ed), 1979, Agama, Etos Kerja dan Perkembangan Ekonomi, Jakarta: LP3ES

Bagian Humas Pemerintah Kota Malang, 2002, Sekilas Kota Malang, Malang: tp

Bapedalda Kota Malang, 2004, Buku I Analisis Lingklungan Hidup, Malang: Bapedalda

Bapeko Pemerintah Kota Malang, 2004, Basis Data Kota Malang 2004, Malang, tp

Biro Pusat Statistik Kota Malang dalam Angka 2009

Bungin, Burhan, 2003, Analisis Data Penelitian Kualitatif Pemahaman Filosofis dan Metodologis ke Arah Penguasaan Model Aplikasi, Jakarta: PT RajaGrafindo Persada

de Jonge, Huub, 1989, Madura dalam Empat Zaman: Pedagang, Perkembangan Ekonomi, dan Islam, Jakarta: PT. Gramedia

Dhavamony, Mariasusai, 1995, Fenomenologi Agama, ter. A. Sudiarja, dkk., Yogyakarta: Penerbit Kanisius

Dhofir, Zamakhsyari, 1982, Tradisi Pesantren: Studi tentang Pandangan Hidup Kyai, Jakarta: LP3ES

Djauhari, Moh. Tidjani, 1996, "Peran Islam dalam Pembentukan Etos Masyarakat Madura," dalam Ruh Islam dalam Budaya Bangsa: Aneka Budaya di Jawa, Jakarta: Yayasan Festival Istiqlal

Djakfar, Muhammad, 2009, Anatomi Perilaku Bisnis: Dialektika Etika dengan Realitas, Malang: UIN Malang Press 
Effendy, Bahtiar, "Pertumbuhan Etos Kerja Kewirausahaan dan Etika Bisnis di Kalangan Muslim," dalam Bahtiar Effendy, 2001, Masyarakat Agama dan Pluralisme Keagamaan, Yogyakarta: Galang Press

Humas KKM, 1996, Malang Kucecwara, Malang: Humas KKM.

, 1998, Potret Kotamadya Malang 1988-1998, Malang: tp

, 1998, Sekilas Kota Malang, Malang: Humas KKM

Imron, D. Zawawi, 1996, "Peta Estetik Madura Masa Lalu," dalam Ruh Islam dalam Budaya Bangsa: Aneka Budaya di Jawa, Jakarta: Yayasan Festival Istiqlal

Kuntowijoyo, 2002, Madura 1850-1940, Yogyakarta: Mata Bangsa

Mansurnoor, Iik Arifin, 1990, Islam in Indonesian World, Ulama of Madura, Yogyakarta: Gajah Mada University Press

Natsir, H. Nanat Fatah, 1999, Etos Kerja Wirausahawan Muslim (Disertasi), Bandung: Gunung Djati Press

Nilam, Muhammad, "Perilaku Bisnis Orang Madura Kontemporer," dalam Aswab Mahasin (ed) , et.al., 1996, Ruh Islam dalam Budaya Bangsa, Jakarta: Yayasan Festival Istiqlal

Poerwadarminta, W.J.S., 1986, Kamus Umum Bahasa Indonesia, Jakarta: Balai Pustaka

Qodir, Zuly, 2002, Agama \& Etos Kerja Dagang, Solo: Pondok Edukasi

Sobary, Muhammad, 1995., Kesalehan dan Tingkah Laku Ekonomi, Yogyakarta: Penerbit Yayasan Bentang Budaya

Subaharianto, Andang, dkk, 2004, Tantangan Industrialisasi Madura Membentur Kultur, Menjunjung Leluhur, Malang: Bayumedia

Swasono, Sri-Edi, Menuju Entrepreneurial University, Bahan Seminar Sehari Dalam Rangka Dies Natalis Universitas Brawijaya ke 41, 29 Januari 2005

Syamsuddin, Muh., "Agama dan Perilaku Ekonomi Migran Madura di Yogyakarta", dalam Jurnal Penelitian Agama Vol. X No. 3 September-Desember 2001, Pusat Penelitian IAIN Sunan Kalijaga Yogyakarta

Tim Peneliti, Pelayanan Orangtua dalam Mendorong Keberhasilan Belajar Anak di Sekolah Menengah Atas Negeri di Madura, Pamekasan: Proyek Peningkatan Perguruan Tinggi Agama IAIN Sunan Ampel Fakultas Tarbiyah Pamekasan Tahun Anggaran 1994/1995, 1994

Triyuwono, Iwan, "Spiritualitas Etos Kerja dan Etika Bisnis Oreng Meddhurah", dalam Muhammad Djakfar, 2009, Anatomi Perilaku Bisnis: Dialektika Etika dengan Realitas, Malang: UIN Malang Press 
Weber, Max, 2003, Etika Protestan dan Semangat Kapitalisme, ter. Yusup Priasudiarja, Pustaka Promethea

Wiyata, A. Latief, 2002, Carok: Konflik Kekerasan dan Harga Diri Orang Madura, Yogyakarta: LkiS 